\title{
Threatened species to super-abundance: The unexpected international implications of successful goose conservation
}

\author{
Anthony D. Fox, Jesper Madsen
}

\begin{abstract}
Wild geese wintering in western Europe were declining by the 1930s probably due to loss of natural habitat and over exploitation through hunting, although the causes will never be known. Refuge provision and hunting restrictions from the 1950s enabled numbers to recover. Improved monitoring systems enabled the description of progressive increases and extensions of wintering range since that time, especially amongst those goose populations that increasingly exploited agricultural landscapes. This introductory article sets the scene for the special issue on the increasing interactions and conflicts created by recent increases in the range and abundance of wild geese throughout the northern hemisphere, especially with regard to agricultural damage, but including issues associated with air flight safety, human and animal health, ecosystem effects and conflicts with other biodiversity objectives. It also provides the context for finding common solutions to problems, presenting experiences from regional-, national- and flywaycoordinated management to find solutions to conflict.
\end{abstract}

Keywords Geese and agriculture - Goose hunting · Over exploitation - Population growth · Protection . Refuge

\section{INTRODUCTION: THE AWAKENING OF WESTERN EUROPEAN CONSERVATION AWARENESS}

When one reads the heroic tales of the mass slaughter of geese by the great British wildfowlers of the nineteenth century, one could be forgiven for thinking that the 1800 s were a period of enormous goose abundance in the United Kingdom, characterised by skies black with geese and unimaginable daily bags (e.g. Folkard 1859; Hawker 1893; Chapman 1928). By comparison, much later, seen from the standpoint of western European observers in the 1930s, there seemed good reason to believe that there had been catastrophic declines in many wildfowl species, including geese, during the first half of the last century. This belief gave rise to the instigation of an International Wildfowl Inquiry into the European status of ducks and geese (Berry $1939 \mathrm{a}, \mathrm{b})$ by the British Section of the International Committee for Bird Preservation (the precursor of BirdLife International).

The evidence gathered by the Inquiry suggested that goose populations had been, and at that time continued to be, threatened by over exploitation through the improvement and accessibility of firearms, the economic development of much marginal and wetland habitat across Europe, and what was then also considered to be unsustainable exploitation on breeding areas [much later revealed by Storå (1968) and Nowak (1995)]. This led the Inquiry to conclude that there was a radical need to instigate protection of geese and habitats to restore them to what we might now call favourable conservation status. There was no doubt that even before the Second World War, some goose populations were in trouble. For some species, this was the result of long-term effects of persecution, as was the case for the greylag goose Anser anser which was extirpated as a breeding bird throughout much of England in the late 1700s and had become restricted to a few Hebridean breeding refugia by the 1880s (Holloway 1996). Wintering numbers of various goose species in the Rhine-Meuse Delta (a current stronghold for several species) were considered "on the brink of extinction" by the 1930s (Neinhuis 2008). Furthermore, the "wasting disease" of Zostera associated with the mycetozoan Labyrinthula in the Northern Hemisphere that affected extensive areas of this 
plant in 1931 and 1932 had a profound effect on the brent goose Branta bernicla populations that almost exclusively relied on this winter food source (Cottam et al. 1944; Cottam and Munro 1954; Rasmussen 1977), although it has been argued that exploitation may have controlled the remaining small populations (Madsen 1987; Ebbinge 1991). On a continent already ravaged by the Second World War, post war reconstruction went on to contribute to the destruction and degradation of wetlands and natural goose habitat across Europe. Poorly or unrestricted regulation of hunting (often commercially motivated) by a hungry populace further adversely impacted populations. In the 1950s, there were very few protected areas for any form of wildlife and even as rudimentary site-safeguard mechanisms began to emerge, for geese these were typically only night time roosts leaving them vulnerable to wildfowling during their feeding flights elsewhere. Goose population structure, flyways, status, abundance, trends and distribution were still poorly known.

\section{CHANGING ATTITUDES AND RESTRICTIVE HUNTING LEGISLATION: THE CASE OF THE UNITED KINGDOM}

All this began to change radically at the beginning of the 1950s. Knowledge of flyways improved through the capture and individual marking of geese with metal rings thanks to pioneers such as Sir Peter Scott's Severn Wildfowl Trust (e.g. Scott et al. 1953). These generated patterns of ringing recoveries that enabled definition of discrete flyway populations that used separate breeding, moulting, staging and wintering areas (e.g. Boyd and Scott 1955). Knowledge of these relationships enabled coordinated international counts to assess discrete population sizes and to start annual surveillance which, over time, generated knowledge about changes in abundance (e.g. Boyd 1961). These pioneering attempts at census generally painted a picture of slowly increasing numbers, but concern still focussed upon the fact that in the 1950s, many of these populations were thought to be showing the first signs of recovery from very low population levels. This meant that conservation actions were necessary to support their continued growth, primarily through regulation of hunting pressure prevailing at the time.

Spring shooting of geese had been made unlawful in the United Kingdom as long ago as 1881, but hunting generally continued to adversely impact upon populations between the World Wars. In the UK, the Duck and Goose Act of 1939 protected wildfowl from hunting between 1 February and 11 August and the 1954 Protection of Birds Act outlawed large barrelled guns above $4.5-\mathrm{cm}$ diameter and removed brent and barnacle geese Branta leucopsis entirely from the hunting list. The legislation was strengthened in 1967 by prohibiting the marketing of shot geese, which was the final piece of legislation making a substantial difference to the level of shooting mortality across all wild goose species in the United Kingdom (although single species legislation followed with the 1981 Wildlife and Countryside Act).

\section{Development of protected area networks in the United Kingdom}

As well as reducing hunting mortality, it was also recognised that much of the habitat used by geese was under threat from development pressures. The few protected areas that existed prior to the 1950s in the UK were greatly limited in extent and distribution, and typically restricted to roost areas only. At that time, the Nature Conservancy UK established a Wildfowl Conservation Committee, who recognised "...that an adequate and suitably administered series of wildfowl refuges form a desirable and, in some conditions, an indispensable means of conserving and increasing wildfowl stocks, in which wildfowlers are no less interested than protectionists and scientists" (Wildfowl Conservation Committee 1961). National Wildfowl Refuges were established from 1955 onwards on the Humber Estuary, at Southport on the Ribble Estuary and Caerlaverock on the Solway Firth in Scotland and were complemented by networks of National Nature Reserves and Sites of Special Scientific Interest which enabled site protection under the provisions of the National Parks and Access to the Countryside Act 1949 (see Ratcliffe 1977; Poore and Gryn-Ambroes 1980). Nonetheless even in the 1960s, there were no effective international frameworks within which to start to develop cohesive site-safeguard networks or coordinated approaches to hunting exploitation other than at national scales, while overall knowledge of numbers and trends remained extremely poor.

\section{RESULTS OF RECENT POPULATION MONITORING}

Knowledge of discrete population flyways and abundance are now essential foundations for the constructions of sitesafeguard networks, so, for instance, the designation of key sites supporting more than $1 \%$ of goose flyway populations underpins the UK's commitments under contemporary legislation such as designating Wetlands of International Importance under the Ramsar Convention and contributes to designation of Special Protection Areas under the EU Bird's Directive (Stroud et al. 2001, 2016).

In the face of our still relatively flawed modern monitoring programmes, it is important to remember the 
limitations of historical goose abundance data for drawing any significant inference about genuine changes in abundance. The recent review of the status and abundance of 69 populations of 15 species of northern hemisphere geese found that less than half of all current estimates of population size were likely to fall within $10 \%$ of the true number, and most of the best estimates were from North American populations (Fox and Leafloor unpublished results). None of the time series that exist extend before the early 1950s. For this reason, it is extraordinarily difficult to assess the population size of many goose populations before the middle of the last century. Despite this lack of historical context, our current knowledge has been invaluable for establishing the general abundance and recent trends in most western European goose populations. Furthermore, marking programmes throughout the latter half of the last century has contributed enormously to improve our understanding of flyway population definition. All these monitoring programmes show that numbers of geese of the majority, but not all, of western European goose populations have increased dramatically in Europe since 1960s (e.g. Fox et al. 2010; Fox and Leafloor unpublished results). Many of these populations show unchecked exponential increase since systematic counting began (Fig. 1), although a few show stabilisation and recent declines (Fig. 2). Of 17 populations with known longerterm trends in western Europe, 14 are currently showing significant exponential increases and only three declining (Table 1). The seven goose populations in the United Kingdom that summed to 100000 birds in the 1950s now number over a million individuals (Mitchell et al. 2010).

\section{CHANGES IN HABITAT USE: THE SWITCH FROM NATURAL TO AGRICULTURAL FOODS}

While it is tempting to suggest that reductions in hunting mortality and the designation of protected areas supported the expansion in numbers of geese in western Europe, we have no data on the specific effects of these actions on goose demography to support these hypotheses from that time. Furthermore, it is clear from the counts in very recent years that exponential increases in numbers of many goose populations continue (e.g. Fig 1; Table 1) and many populations that specifically exploit agricultural habitats show expansions in wintering range.

A feature associated with many increases in goose population size has been the shift in their habitat utilisation from natural wetlands to temperate farmland landscapes where they have become adept at exploiting agricultural crops and all forms of managed grassland (e.g. Abraham et al. 2005; Fox et al. 2005; Fox and Abraham 2017). This
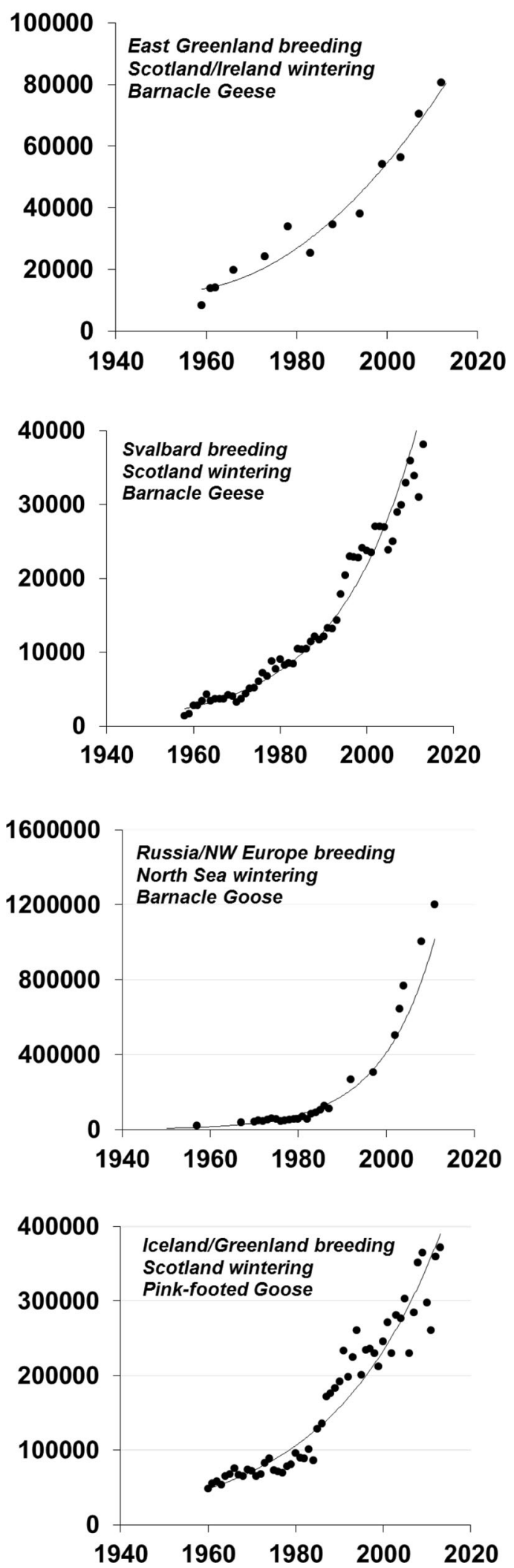

Fig. 1 Examples of four populations of western European goose populations showing current exponential growth (from Fox and Leafloor unpublished results) 

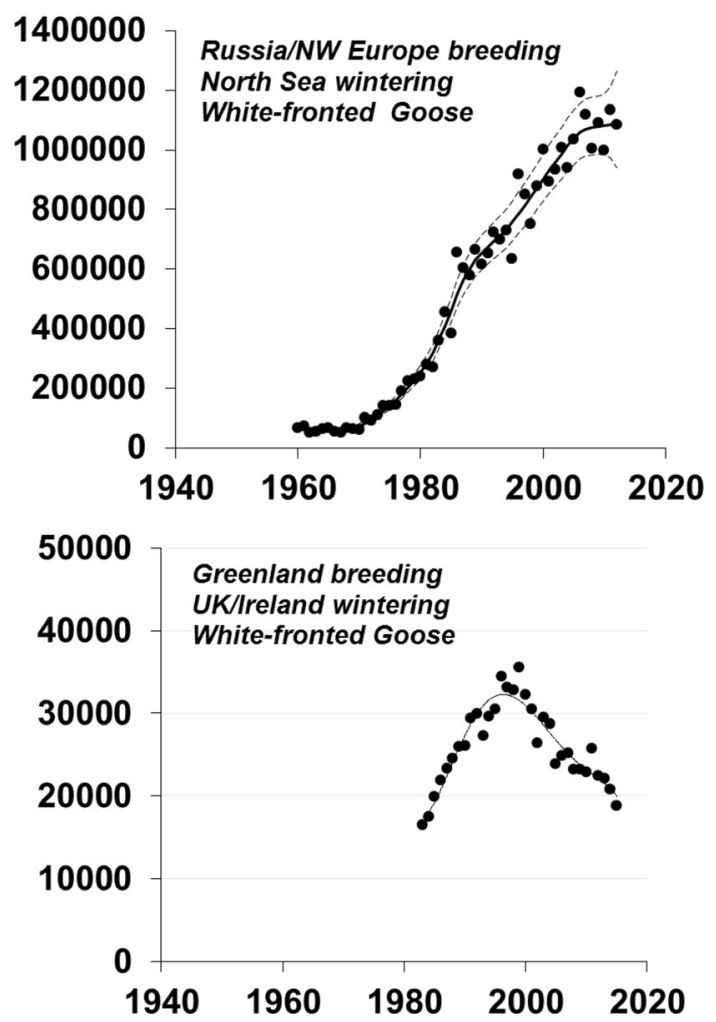

Fig. 2 Examples of two populations of western European goose populations showing stabilisation (upper Anser albifrons albifrons showing modelled 95\% confidence intervals) or decline (lower A.a. flavirostris) in growth rates (from Fox and Leafloor unpublished results) would suggest that temperate agriculture has been highly effective at extending the effective carrying capacity of wintering goose numbers (van Eerden et al. 1996). As large herbivorous birds with a relatively simple gut structure, geese have traditionally aggregated to natural plant communities that offer a dense source of food (Fox et al. 2017). For instance, several short-billed goose species traditionally grazed the above ground biomass of short sward, graminoid-dominated low diversity plant communities. Such communities can be found in the intertidal (where geese graze Zostera) and subtidal (where geese up-end to browse submerged Zostera) in the case of many populations of brent geese on salt stressed grasslands, such as saltmarshes (e.g. Svalbard and Greenland barnacle geese and dark-bellied brent geese $B . b$. bernicla) and clifftop and dune grassland (Greenland barnacle geese). Now, the same goose species find such highly nutritious short swards in agricultural and other artificial landscapes, such as in intensively managed pasture, amenity grasslands and winter cereal fields. Other goose species with more robust bills and necks combine grazing of longer, coarser swards [e.g. western taiga bean geese Anser fabalis fabalis (Allport 1991)] with digging in wet substrates to extract the below ground overwinter perenniating parts of plants [such as Scirpus species in saltmarshes in the case of greylag and snow geese Chen caerulescens (Amat 1995), and Eriophorum angustifolium in surface patterned mires in the

Table 1 The most recent estimated population sizes of 17 wild goose populations in western Europe as reviewed in Fox and Leafloor (unpublished results). Columns also provide the year of the estimate, as well as the longer-term ( $>10$ years but time series depending on population) trends expressed as percentage rate of change per annum, together with the duration of the period use to calculate these trends

\begin{tabular}{|c|c|c|c|c|}
\hline Goose species and population & $\begin{array}{l}\text { Estimated } \\
\text { population size }\end{array}$ & $\begin{array}{l}\text { Year of } \\
\text { estimate }\end{array}$ & $\begin{array}{l}\% \text { rate of change } \\
\text { per annum }\end{array}$ & $\begin{array}{l}\text { Period of rate } \\
\text { of change }\end{array}$ \\
\hline Taiga Bean Goose Anser fabalis fabalis & 52000 & 2015 & -6.0 & 2006-2015 \\
\hline Tundra Bean Goose Anser fabalis rossicus & 600000 & 2014 & +2.6 & 1990-2013 \\
\hline Iceland Pink-footed Goose Anser brachyrhynchus & 360000 & 2013 & +3.9 & 1960-2013 \\
\hline Svalbard Pink-footed Goose Anser brachyrhynchus & 76000 & 2014 & +3.6 & $1965-2013$ \\
\hline $\begin{array}{l}\text { Baltic-North Sea wintering White-fronted Goose Anser } \\
\text { albifrons albifrons }\end{array}$ & 1085000 & 2012 & +2.5 & 1988-2012 \\
\hline Greenland White-fronted Goose Anser albifrons flavirostris & 18900 & 2015 & -2.8 & 1999-2014 \\
\hline Scandinavian Lesser White-fronted Goose Anser erythropus & 80 & 2010 & -5.0 & $1993-2008$ \\
\hline Iceland Greylag Goose Anser anser & 100000 & 2014 & +1.5 & $1960-2013$ \\
\hline UK breeding Greylag Goose Anser anser & 140000 & 2014 & +9.4 & $1998-2008$ \\
\hline NW Europe breeding Greylag Goose Anser anser & 960000 & 2014 & +8.5 & $1980-2008$ \\
\hline Central European Greylag Goose Anser anser & 100000 & 2014 & +6.8 & $1995-2008$ \\
\hline Greenland Barnacle Goose Branta leucopsis & 80500 & 2013 & +3.6 & 1959-2012 \\
\hline Svalbard Barnacle Goose Branta leucopsis & 38000 & 2013 & +6.6 & $1956-2013$ \\
\hline Russia/Baltic/North Sea Barnacle Goose Branta leucopsis & 1200000 & 2015 & +7.8 & 1960-2014 \\
\hline Russian Dark-bellied Brent Goose Branta bernicla bernicla & 211000 & 2011 & +5.6 & $1956-2010$ \\
\hline NE Canada light-bellied Brent Goose Branta bernicla hrota & 48000 & 2011 & +4.4 & $1996-2013$ \\
\hline Svalbard light-bellied Brent Goose Branta bernicla hrota & 7500 & 2015 & +2.4 & $1987-2015$ \\
\hline
\end{tabular}


case of the Greenland white-fronted geese A. albifrons flavirostris (Ruttledge 1929; Fox et al. 1990)]. These goose species now find such food in the form of agricultural products, such a root crops (e.g. potatoes and beet) and grain (especially cereal and maize left after the harvest).

In western Europe, intensification of agriculture has increasingly made farmland landscapes homogeneous, stimulated by technological change and the EU's Common Agricultural Policy. Although St. Werburgh was banishing geese from English fields in the seventh century (Kear 2001), until the last 70 years, agriculture has never served up such rich monocultures of goose food as is the case in contemporary Europe. Serried ranks of sown rows of single species of grass and arable crops, waste root crops, unharvested and spilled cereal grains (all selectively bred for their food quality) provide monocultures of high quality food for geese. Such resources support unimaginably high food intake rates compared to those possible when foraging on saltmarshes or even low intensity pastures, where birds are constrained to search amongst diverse swards for the most nutritionally rewarding grass blades or other sources of wild foods (e.g. Madsen 1985; Therkildsen and Madsen 2000; Fox et al. 2005; Fox and Abraham 2017). Little wonder that, in response, geese have progressively abandoned their natural habitats to exploit this larder of superabundance and, when scared away, show little desire to abandon nutritionally rich agricultural fields for the natural and semi-natural habitats that were exclusively their former natural foraging habitats.

However, in making these transitions, these patterns have created a series of problems and challenges to a range of stakeholders and government agencies for the effective management of goose populations. For example, Chapman (1928) described brent geese as never touching “...British soil, being exclusively marine...they sleep at sea and only enter tidal mud-flats to feed...never go inland, nor trespass a single yard above the full sea-mark". Yet by the early 1980s the species had begun to feed on pasture, winter cereal and oil seed rape over the seawall from their former saltmarsh and Zostera beds in southern Britain to the extent that they had become a cause of major loss of income to farmers and a major locus for conflict (e.g. Vickery and Summers 1992; McKay et al. 1993, 1994, 1996a, b; Vickery et al. 1994). In Ireland, brent geese now regularly feed amongst dog walkers and football players in Dublin parks.

There is little convincing evidence that the move by geese from feeding on natural or semi-natural habitats to completely artificial ecosystems has had impacts at the population level. The only study to establish a link between demographical parameters and the shifts to agricultural feeding comes from the study of winter site-faithful Greenland white-fronted geese, which showed flocks wintering on intensively managed agricultural land produced
$10 \%$ more young than those that remained feeding exclusively on natural peat bog vegetation (which were numerically far smaller and therefore contributed very much fewer young to future generations than did farmland flocks, Fox et al. 2005).

Despite our inability to directly link the switch from natural wetlands to farmland with increases in population size, support for this hypothesis comes from the East Asian flyway populations of geese. In China, human persecution on farmland means that wintering wild goose populations remain almost entirely dependent on wetlands for feeding in winter. Most wintering goose species are declining in China because of the hydrological and trophic changes in wetlands that are increasingly denying them of food (e.g. Fox et al. 2011; Zhao et al. 2012; Wang et al. 2013). The exception is the eastern tundra bean goose, Anser fabalis serrirostris, which does feed on farmland and which seems to be maintaining stable or increasing numbers (Zhao et al. 2010; Jia et al. 2016). Furthermore, some of the same goose species that are declining in China feed on spilled wheat and rice grains in Korea and Japan where their wintering numbers are showing similar increases to continental North America and Europe. This demonstrates that the same goose species within the same flyway thrive on farmland in situations where they are free to exploit such sources of food (Jia et al. 2016) and supports the hypothesis that the shift to farmland has contributed to increases in abundance.

While there is only circumstantial evidence that the shift from natural habitats to agricultural ones has fuelled the rapid increase to specific goose populations in recent years, the fact remains that now these herbivorous birds have learnt to exploit such landscapes, the modern farmland of their wintering range offers currently unlimited access to food during the non-breeding periods of the annual cycle, which means that winter forage in the immediate future is not likely to be a limiting factor. That said, the increasing reliance on agricultural landscapes of goose populations in Europe and North America does make them dependent upon current patterns of cropping and agriculture. This puts goose populations at the mercy of major changes to the farming landscape patterns brought about by globalisation, politics, climate change and farming developments which may conspire to drive agricultural change in unpredictable ways that will not necessarily be beneficial for geese in the future (Fox and Abraham 2017).

Since the exponential increases in most common goose populations show little sign of stabilising (however, see Fig. 2), this may also be the case for the breeding areas as well. Some studies show that increasing goose populations wintering in temperate regions may have major local impacts on Arctic ecosystems in the form of eutrophication and reduction of vegetation cover as a result of grazing (Madsen et al. 2011; Hassen et al. 2016). Hence, increases 
in goose abundance may have longer-term negative consequences for the number of geese the habitat can sustain. In general, however, we see few signs of strong density dependence at the population level that might limit the growth rate of these populations in the near future.

\section{FINDING SOLUTIONS TO CONFLICTS CAUSED BY INCREASING GOOSE ABUNDANCE: AN INTRODUCTION TO ARTICLES IN THIS SPECIAL ISSUE}

As numbers of wintering geese have increased in Europe, so the degree and geographical extent of conflict with farming interests has increased as a recent review has shown (Fox et al. 2017). However, it has become increasingly apparent that despite the primary focus in the agricultural arena, issues associated with air flight safety, human and animal health, ecosystem effects and conflict with other biodiversity objectives have also been rising up the political agenda.

These multiple societal challenges require careful integration for their successful resolution, and the aim of this special issue of Ambio is to bring together some of the most experienced professionals in their fields to review the strengths and weaknesses of existing attempts to integrate these multiple challenges in cohesive goose management programmes. In particular, effective mechanisms for integrating diverse and conflicting interests, using interdisciplinary approaches at local, regional, national and flyway scales are sought, incorporating participatory and adaptive approaches. Lefebvre et al. (2017) and Madsen et al. (2017) review some of the fundamentals of what causes conflict in relation to specific populations of wild geese and some of the mechanisms for deconstructing and finding solutions to such conflicts. Inevitably, there is considerable need for emphasis upon understanding the nature of the conflict between geese and agriculture. Simonsen et al. (2017) consider scaring as a tool to alleviate crop damage by geese, but also look at how farmers perceive goose damage. They show that the degree of scaring effort invested by a farmer is not necessarily a direct function of goose use of his farm, underlining the need to better understand the sociological factors that shape perceptions in these and other such conflicts. Assessing effectiveness of regional management is undertaken specifically with respect to agriculture in Norway by Baveco et al. (2017), complemented by a review of the success and value of key approaches to resolving conflict on the Scottish island of Islay (McKenzie and Shaw 2017). Islay experiences particular problems because of the internationally important concentrations of goose populations of conservation importance which occur on the island and contribute to the green economy there, but that nevertheless cause conflict with farmer's incomes (McKenzie and Shaw 2017). The Islay case study is also set in the context of examining how regional management fits within the context of a national strategy and how it compares with other goose management schemes throughout Scotland (Bainbridge 2017). We also try to understand the strengths and weaknesses of national approaches that have been tried and tested in Norway (Eythórsson et al. 2017), the Netherlands (Koffijberg et al. 2017) and how effective interventions against burgeoning numbers of breeding geese are being dealt with in the Netherlands as this important issue begins to rise up the agendas of western European governments (van der Jeugd and Kwak 2017). Overabundant geese populations have been a problem recognised for a rather longer time period in North America than in Europe. For this reason, we also review how American plans for managing goose populations have progressed, delivered and developed with particular emphasis on delivering key recommendations about pitfalls to avoid as well as concentrating on highlighting the best mechanisms for delivery (e.g. Lefebvre et al. 2017). Many of the experiences associated with adaptive harvest management gained in North America have been applied to a pioneering process applied to the Svalbard-breeding population of the pink-footed goose and the knowledge gained at every step in the development of this unique European management system is presented in Madsen et al. (2017). It is also becoming abundantly evident that changes in goose abundance are having considerable societal and ecological impacts away from commercial damage to agricultural interests, so we summarise available experiences arising from the increase in air flight safety issues related to geese associated with airports around the world (Bradbeer et al. 2017) as well as reviewing the knock-on effects of goose distribution and abundance on ecosystems and other organisms in general (Buij et al. 2017). Finally, we round off with a summary and synthesis of the entire exercise where specific recommendations are made to take the process forward (Stroud et al. 2017). There was clearly a very pressing need for such a synthesis and we are confident that we have been able to gather a unique set of experiences from practitioners around the globe from which to distill the most effective mechanisms available to form the basis for taking forward ideas about how to mount a successful integrated, multi-layered approach to goose management at a strategic level in the future.

Acknowledgements We gratefully acknowledge the selfless contributions of all the participants of the international conference "Goose management challenges 2015" held at Gram Slot in southern Jutland, Denmark on 27-29 October 2015. The conference was organised jointly by the Danish Nature Agency, Ministry of Environment and Food and Aarhus University and sponsored by the Danish Nature 
Agency, the Ministry of Environment and Food, The Norwegian Environment Agency, The Danish Wadden Sea National Park, BIJ12Faunafonds, The Netherlands and Aarhus University. We would especially like to thank Bent Rasmussen and Jan Steinbring Jensen of the Danish Nature Agency, Camilla Uldal of the Danish Agency for Water and Nature Management and John Frikke, Wadden Sea National Park for their work for and support of the conference. We are indebted to our very many friends, collaborators and colleagues who have supported the work that has gone into this work, too many to mention.

Open Access This article is distributed under the terms of the Creative Commons Attribution 4.0 International License (http:// creativecommons.org/licenses/by/4.0/), which permits unrestricted use, distribution, and reproduction in any medium, provided you give appropriate credit to the original author(s) and the source, provide a link to the Creative Commons license, and indicate if changes were made.

\section{REFERENCES}

Abraham, K.F., R.L. Jefferies, and R.T. Alisauskas. 2005. The dynamics of landscape change and snow geese in mid-continent North America. Global Change Biology 11: 841-855.

Allport, G.A. 1991. The feeding ecology and habitat requirements of overwintering western taiga bean geese (Anser fabalis fabalis). $\mathrm{PhD}$ thesis. University of East Anglia.

Amat, J. 1995. Effects of wintering Greylag Geese Anser anser on their Scirpus food plants. Ecography 18: 155-163.

Bainbridge, I. 2017. Goose management in Scotland: An overview. Ambio. doi:10.1007/s13280-016-0883-5.

Baveco, J.M., A.-K. Bergjord, J.W. Bjerke, M.E. Chudzińska, L. Pellissier, C.E. Simonsen, J. Madsen, I.M. Tombre, et al. 2017. Combining modelling tools to evaluate a goose management scheme. Ambio. doi:10.1007/s13280-017-0899-5.

Berry, J. 1939a. Factors affecting the general status of wild geese and wild duck. International wildfowl inquiry, vol. 1. Cambridge: University Press.

Berry, J. 1939b. The status and distribution of wild geese and wild duck in Scotland.' Inter- national Wildfowl Inquiry, vol. 2. Cambridge: University Press.

Boyd, H. 1961. The number of Barnacle Geese in Europe in 1959-1960. Wildfowl Trust Annual Report 12: 116-124.

Boyd, H., and P. Scott. 1955. The British population of the Pinkfooted Goose, its numbers and annual losses. Wildfowl Trust Annual Report 7: 99-106.

Bradbeer, D.R., C. Rosenquist, T.K. Christensen, and A.D. Fox. 2017. Crowded skies: Conflicts between expanding goose populations and aviation safety. Ambio. doi:10.1007/s13280-017-0901-2.

Buij, R., Th.C.P. Melman, M.J.J.E. Loonen, and A.D. Fox. 2017. Balancing ecosystem function, services and disservices resulting from expanding goose populations. Ambio. doi:10.1007/s13280017-0902-1.

Cottam, C., and D.A. Munro. 1954. Eelgrass status and environmental relations. Journal of Wildlife Management 18: 449-460.

Cottam, C., J.J. Lynch, and A.L. Nelson. 1944. Food habits and management of American sea brant. Journal of Wildlife Management 8: 36-56.

Chapman, A. 1928. Retrospect: Reminiscences and impressions of a hunter-naturalist in three continents 1851-1928. London: Gurney and Jackson.

Ebbinge, B.S. 1991. The impact of hunting on mortality-rates and spatial distribution of geese wintering in the Western Palearctic. Ardea 79: 197-209.
Eythórsson. E., I.M. Tombre, and J. Madsen. 2017. Goose management schemes to resolve conflicts with agriculture: Theory, practice and effects. Ambio. doi:10.1007/s13280-016-0884-4.

Folkard, H.C. 1859. The wild-fowler: A treatise on ancient and modern wild-fowling, historical and practical. London: Piper, Stephenson and Spence.

Fox, A.D., and K.F. Abraham. 2017. Why geese benefit from the transition from natural vegetation to agriculture. Ambio. doi:10. 1007/s13280-016-0879-1.

Fox, A.D., D.A. Stroud, and I.S. Francis. 1990. Up-rooted common cotton-grass Eriophorum angustifolium as evidence of goose feeding in Britain and Ireland. Bird Study 37: 210-212.

Fox, A.D., J. Madsen, H. Boyd, E. Kuijken, D.W. Norriss, I.M. Tombre, and D.A. Stroud. 2005. Effects of agricultural change on abundance, fitness components and distribution of two arctic-nesting goose populations. Global Change Biology 11: 881-893.

Fox, A.D., B.S. Ebbinge, C. Mitchell, T. Heinicke, T. Aarvak, K. Colhoun, P. Clausen, S. Dereliev, et al. 2010. Current estimates of goose population sizes in the western Palearctic, a gap analysis and an assessment of trends. Ornis Svecica 20: 115-127.

Fox, A.D., L. Cao, Y. Zhang, M. Barter, M.J. Zhao, F.J. Meng, and S.L. Wang. 2011. Declines in the tuber-feeding waterbird guild at Shengjin Lake National Nature Reserve, China-a barometer of submerged macrophyte collapse? Aquatic Conservation: Marine and Freshwater Ecosystems 21: 82-91.

Fox, A.D., J. Elmberg, I. Tombre, and R. Hessel. 2017. Agriculture and herbivorous waterfowl: A review of the scientific basis for improved management. Biological Reviews. doi:10.1111/brv. 12258.

Hawker, P. 1893. The diary of Colonel Peter Hawker, 1802-1853. London: Longmans, Green and Co.

Hessen, D.O., I.M. Tombre, G. van Geest, and K. Alfsnes. 2016. Global change and ecosystem connectivity: How geese link fields of central Europe to eutrophication of Arctic freshwaters. Ambio 46: 40-47. doi:10.1007/s13280-016-0802-9.

Holloway, S. 1996. The historical atlas of breeding birds in Britain and Ireland 1875-1900. London: T. and A.D. Poyser.

Jia, Q., K. Koyama, C.-Y. Choi, H.-J. Kim, L. Cao, D. Gao, G. Liu, and A.D. Fox. 2016. Population estimates and geographical distribution of swans and geese in East Asia based on counts during the non-breeding season. Bird Conservation International 26: 397-417. doi:10.1017/S0959270915000386.

Kear, J. 2001. Three early medieval accounts of agricultural damage by wild geese. Archives of Natural History 28: 245-255.

Koffijberg, K., H. Schekkerman, H. van der Jeugd, M. Hornman, and E. van Winden. 2017. Responses of wintering geese to the designation of goose foraging areas in The Netherlands. Ambio. doi:10.1007/s13280-016-0885-3.

Lefebvre, J., G. Gauthier, J.-F. Giroux, A. Reed, E.T. Reed, and L. Bélanger. 2017. The greater snow goose Anser caerulescens atlanticus: Managing an overabundant population. Ambio. doi:10.1007/s13280-016-0887-1.

McKay, H.V., J.D. Bishop, C.J. Feare, and M.C. Stevens. 1993. Feeding by brent geese can reduce yield of oilseed rape. Crop Protection 12: 101-105.

McKay, H.V., J.D. Bishop, and D.C. Ennis. 1994. The possible importance of nutritional requirements for dark-bellied brent geese in the seasonal shift from winter cereals to pasture. Ardea 82: $123-132$.

McKay, H.V., S.D. Langton, T.P. Milsom, and C.J. Feare. 1996a. Prediction of field use by brent geese; an aid to management. Crop Protection 15: 259-268.

McKay, H.V., J.D. Bishop, and C.J. Feare. 1996b. Brent goose (Branta bernicla bernicla) diet choice on agricultural land: A synthesis of two studies. Gibier Faune Sauvage 13: 916-925. 
McKenzie, R., and J.M. Shaw. 2017. Reconciling competing values placed upon goose populations: The evolution of and experiences from the Islay Sustainable Goose Management Strategy. Ambio. doi:10.1007/s13280-016-0880-8.

Madsen, J. 1985. Relations between change in spring habitat selection and daily energetics of Pink-footed Geese Anser brachyrhynchus. Ornis Scandinavica 16: 222-228.

Madsen, J. 1987. Status and management of goose populations in Europe, with special reference to populations resting and breeding in Denmark. Danish Review of Game Biology 12: $1-76$.

Madsen, J., C. Jaspers, M. Tamstorf, C.E. Mortensen, and F. Rigét. 2011. Long-term effects of grazing and global warming on the composition and carrying capacity of graminoid marshes for moulting geese in East Greenland. Ambio 40: 638-649.

Madsen, J., J.H. Williams, F.A. Johnson, I.M. Tombre, S. Dereliev, and E. Kuijken. 2017. Implementation of the first adaptive management plan for a European migratory waterbird population: The case of the Svalbard pink-footed goose Anser brachyrhynchus. Ambio. doi:10.1007/s13280-0160888-0.

Mitchell, C., K. Colhoun, A.D. Fox, L. Griffin, C. Hall, R. Hearn, and A.J. Walsh. 2010. Trends in goose numbers wintering in Britain and Ireland, 1960-2006. Ornis Svecica 20: 128-143.

Neinhuis, P.H. 2008. Environmental history of the Rhine-Meuse Delta: An ecological story on evolving human environmental relations coping with climate change and sea level rise. Dordrecht: Springer.

Nowak E (1995) Jagdaktivitäten in der Vergangenheit und heute als Einflußfaktor auf Gänsepopulationen und andere Vögel Nordsibiriens. Corax 16: 143-159.

Poore, D., and P. Gryn-Ambroes. 1980. Nature Conservation in Northern and Western Europe. Report to the United Nations Environment Programme and the International Union for the Conservation of Nature and Natural Resources, Nairobi, Kenya and Gland, Switzerland: UNEP and IUCN.

Rasmussen, E. 1977. The wasting disease of eelgrass (Zostera marina) and its effects on environmental factors and fauna. In Seagrass ecosystems - A scientific perspective, ed. C.P. McRoy, and C. Helfferich, 1-51. New York: Marcel Dekker.

Ratcliffe, D.A. (ed.). 1977. A nature conservation review. Cambridge: University Press.

Ruttledge, R.F. 1929. the birds of Loughs Mask and Carra and surrounding district. Irish Naturalist Journal 11: 223.

Scott, P., J. Fisher, and F. Gudmundsson. 1953. The severn wildfowl trust expedition to Central Iceland, 1951. Report of the Severn Wildfowl Trust 5: 78-115.

Simonsen, C.E., I.M. Tombre, and J. Madsen. 2017. Scaring as a tool to alleviate crop damage by geese: Revealing differences between farmers' perceptions and the scale of the problem. Ambio. doi:10.1007/s13280-016-0891-5.

Storå, N. 1968. Massfångst av sjöfågel i Nordeurasien. Acta Academiae Aboensis Series A 34: 311-313.

Stroud, D.A., D. Chambers, S. Cook, N. Buxton, B. Fraser, P. Clement, P. Lewis, I. McLean, H. Baker, and S. Whitehead (eds.). 2001. The UK SPA network: Its scope and content. Peterborough: Joint Nature Conservation Committee.
Stroud, D.A., I.P. Bainbridge, A. Maddock, S. Anthony, H. Baker, N. Buxton, D. Chambers, I. Enlander, on behalf of the UK SPA \& Ramsar Scientific Working Group, et al. (eds.). 2016. The status of UK SPAs in the 2000s: The third network review. Peterborough: Joint Nature Conservation Committee.

Stroud, D.A., J. Madsen, and A.D. Fox. 2017. Key actions towards the sustainable management of European geese. Ambio. doi:10. 1007/s13280-017-0903-0.

Therkildsen, O.R., and J. Madsen. 2000. Assessment of food intake rates in pink-footed geese Anser brachyrhynchus based on examination of oesophagus contents. Wildlife Biology 6: $167-172$.

van der Jeugd, H.P., and A. Kwak. 2017. Management of a Dutch resident barnacle goose Branta leucopsis population: How can results from counts, ringing and hunting bag statistics be reconciled? Ambio. doi:10.1007/s13280-017-0900-3.

Van Eerden, M.R., M. Zijlstra, M. Van Roomen, and A. Timmerman. 1996. The response of Anatidae to changes in agricultural practice: Long-term shifts in the carrying capacity of wintering waterfowl. Gibier Faune Sauvage 13: 681-706.

Vickery, J.A., and R.W. Summers. 1992. Cost effectiveness of scaring brent geese Branta $b$. bernicla from fields of arable crops by a human bird scarer. Crop Protection 11: 480-484.

Vickery, J.A., A.R. Watkinson, and W.J. Sutherland. 1994. The solutions to the brent goose problem: An economic analysis. Journal of Applied Ecology 31: 371-382.

Wang, X., A.D. Fox, P.H. Cong, and L. Cao. 2013. Food constraints explain the restricted distribution of wintering lesser whitefronted Geese Anser erythropus in China. Ibis 155: 576-592.

Wildfowl Conservation Committee. 1961. National Wildfowl Refuges. Wildfowl Trust Annual Report 12: 23-25.

Zhao, M.-J., L. Cao, and A.D. Fox. 2010. Distribution and diet of wintering Bean Geese Anser fabalis serrirostris at Shengjin Lake, Yangtze floodplain, China. Wildfowl 60: 52-63.

Zhao, M., P. Cong, M. Barter, A.D. Fox, and L. Cao. 2012. The changing abundance and distribution of Greater White-fronted Geese Anser albifrons in the Yangtze River floodplain: Impacts of recent hydrological changes. Bird Conservation International 22: $135-143$.

\section{AUTHOR BIOGRAPHIES}

Anthony D. Fox $(\varangle)$ is a Professor of Waterbird Ecology at Aarhus University. His research focuses on applied goose ecology issues throughout the northern hemisphere.

Address: Department of Bioscience, Aarhus University, Kalø, Grenåvej 14, 8410 Rønde, Denmark.

e-mail: tfo@bios.au.dk

Jesper Madsen is a professor at Aarhus University with an extensive experience with studies of human use of nature and its consequences for waterbird behaviour, site use and population dynamics. He has been the lead for several projects linking ecological knowledge to management.

Address: Department of Bioscience, Aarhus University, Kalø, Grenåvej 14, 8410 Rønde, Denmark.

e-mail: jm@bios.au.dk 


\section{(5) Ministry of Environment
and Food of Denmark \\ Agency for Water and \\ Nature Management}

\section{NATIONALPARK 莡 VADEHAVET}
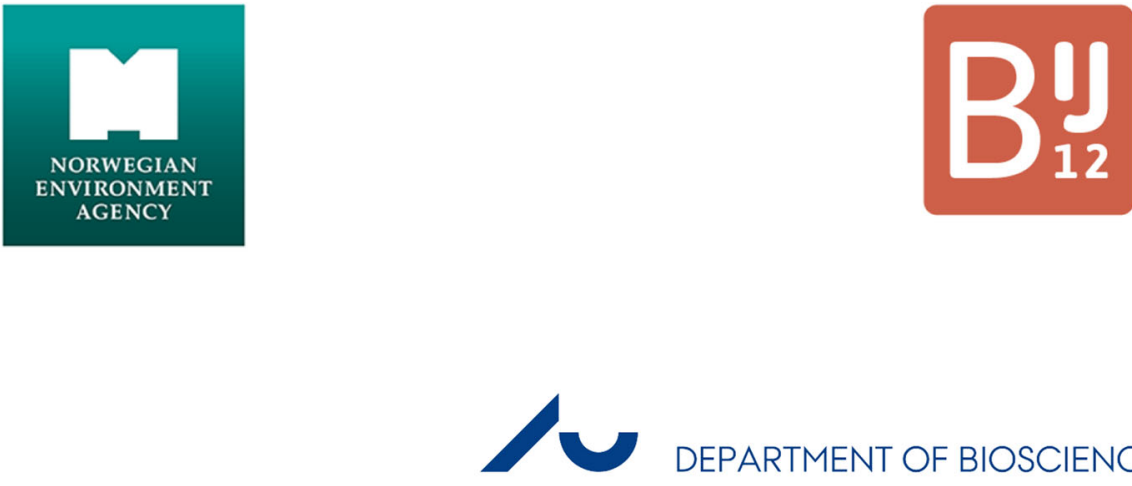

DEPARTMENT OF BIOSCIENCE

AARHUS UNIVERSITY

The International Conference on Goose Management Challenges 2015 held at Gram Slot, Denmark, 27-29 October 2015, as well as the production of this volume of proceedings from the meeting, was generously sponsored by The Agency for Water and Nature Management, Ministry of Environment and Food of Denmark, The Norwegian Environment Agency, The Danish Wadden Sea National Park, BIJ12Faunafonds, The Netherlands and Department of Bioscience, Aarhus University 